\title{
Development of Science Literature Instruments Contained Ethnoscience in Science Subject for Class IV Elementary School Students
}

\author{
Nur Khairiyatul Mar'ah', Ani Rusilowati ${ }^{2}$, Eko Purwanti $^{3}$ \\ ${ }^{1}$ Master Program, Student of Primary Education, ${ }^{2,3}$ Master Program, of Primary Education, \\ Universitas Negeri Semarang, Semarang City, Indonesia. \\ Corresponding Author: Nur Khairiyatul mar'ah
}

\begin{abstract}
This study aimed to produce scientific literacy instruments containing ethnoscience for grade IV elementary school on science subject theme number 9 "Kayanya Negeriku" which is valid, reliable, feasible, and practical. This research method used R\&D research with ADDIE research design (analysis, design, development, implementation, and evaluation). The steps developed include design, expert validation, small-scale trials, and large-scale trials. The instrument developed is a reasoned multiple choice instrument. The data collection technique in this development research was a test (multiple choice) and a practicality questionnaire. The results of the validation of scientific literacy instruments containing ethnoscience are valid, the reliability value during small-scale trials was 0.671 and when large-scale trials were 0.711 these values indicate the instrument is reliable. The differentiating power of small-scale questions obtained 20 multiple-choice questions for grade IV elementary school, there were 10 items received, 2 items were accepted but needed to be corrected, and 8 items were corrected. The analysis of large-scale discrepancy from 20 questions contained 11 items for the criteria for the items to be accepted, 3 items were accepted but needed to be corrected, and 6 items were corrected.

Testing results of the difficulty level gained the results of quantitative analysis on a small scale for the level of difficulty of the questions stated that, as many as 2 questions with easy criteria, 13 questions with medium criteria and 5 questions with difficult criteria. While the results of quantitative analysis on a large scale
\end{abstract}

for the level of difficulty of the questions stated that, as many as 3 items with difficult criteria, 17 questions with moderate criteria and for easy criteria were not found in large-scale trials. The practicality of the instrument can be decided based on the percentage of practicality. The percentage obtained from the teacher's assessment is in very practical criteria.

Keywords: Development, Instrument, Science Literacy, Ethnoscience

\section{INTRODUCTION}

Entering the 21st century, the progress of science and technology in various countries has been increasing rapidly. The main key to this progress is the quality of science education applied in learning of each country. Science education as one of the lessons in elementary schools is an important foundation in forming quality human resources (Anggriani et al., 2020). Science/IPA education as a subject in elementary schools is an important foundation in the formation of quality human resources (Ani Rusilowati et al., 2016).

Science education can describe various natural phenomena that occur in daily life. 21st century learning requires skills in scientific literacy, as well as in reading. Scientific literacy according to PISA is understanding, using, evaluating, contemplating, and being directly involved to achieve one's goals, to develop one's 
knowledge and potential and to participate in society (OECD, 2018).

Education is an important investment in producing quality human resources (Sudarmin et al., 2013). One of the efforts to improve quality human resources is through science education. BouJaoude (2002) stated to make decisions and solve problems, science learning is used to obtain an interaction between science and technology and society.

Work are being made by the Indonesian government to support education, especially in science subjects, is participating in several international assessments, including the Trend In International Mathematics and Science Study (TIMSS) and the Program For International Students Assessment (PISA). The aim of taking the TIMSS is to measure the mathematics and science achievement of grade IV and grade VIII students, while the purpose of participating in the PISA is to measure the reading, math, and science literacy of 15-years-old school students.

The achievement of Indonesia's scientific literacy level during 12 years of participation always got ranks fifth from bottom, even though scientific literacy is very important in determining the quality of education in a country (Fu'adah et al., 2017). In general, TIMSS aims to monitor the results of the education system related to student achievement in mathematics and science. TIMSS is conducted regularly every 4 years. Indonesia became one of the countries that became the object of TIMSS in the last four periods.

Based on the PISA report which was just released Tuesday, December 3, 2019, Indonesia's reading score is ranked 72 out of 77 countries, science scores are ranked 70 out of 7 countries (OECD, 2018). The data showed that the level of scientific literacy of students in Indonesia is still very low. The low level of student scientific literacy data is caused by the instrument technique that does not fully accommodate the criteria for assessing scientific literacy (Adawiyah \& Wisudawati, 2017). Rostikawati \&
Permanasari (2016) stated that scientific literacy is not merely the ability to understand scientific processes and be applied to deal with real conditions that occur in the environment.

The essential of understanding scientific literacy, many studies have been conducted to assess scientific literacy for both teachers and students. Azimi et al., (2017) conducted a study whose results showed that scientific literacy was included in learning in understanding concepts and its benefits did not sufficiently contribute to multi-dimensional literacy, namely reading and understanding. One of them is through the development of test instruments. Learning in the 2013 curriculum requires the ability of teachers to develop appropriate instruments. An educator is required to creatively design a teaching material that allows students to directly utilize available learning resources (Aza Nuralita, 2020). One of the learning resources used by students is an evaluation tool that can measure the level of student ability.

The test instrument that prepared by the teacher should be able to measure students' understanding abilities and have the opportunity to apply the knowledge they have obtained, then they can strengthen their scientific literacy. This is in line with what was conveyed by Adawiyah \& Wisudawati (2017) students can apply their learning outcomes in daily life. Trnova (2014) stated that teachers should change teaching styles by emphasizing studentcentered activities, combining them with real activities and creating new models that are expressions of teacher creativity. This is also supported by the research of Sudiatmika et al., (2010) a collection of tests commonly used in school tests more scientific knowledge from cognitive aspects and mathematical calculations, while the process and context aspects escape assessment.

The importance of developing instruments is the first step to determine the extent of students' ability levels in solving problems, so that teachers can map students' 
abilities and design learning programs that are suitable for students' circumstances. Lulu et al., (2016) student development through education starts from exploring basic potentials, which are directed to understand and appreciate and practice knowledge, concepts and facts in life.

There were several reasons why it is important to develop test instruments. The first is it needs to reorient assessment in learning. All this time, the assessment only emphasizes on content, not on scientific literacy such as applying science in daily life, problem solving thinking and some scientific process skills, then measuring students' scientific literacy by exploring concepts, applications and processes of science, students can apply the knowledge they have learned. taught in schools and know the facts of science in everyday life that develop in society, so that students know about science (Haka et al., 2019)

One of the works to measure scientific literacy skills in learning is through an evaluation tool, that is a test sheet. The position of an assessment as an assessment tool is very important in the world of education (Aji et al., 2015). Ariningtyas et al., (2017) stated that to measure scientific literacy ability, several questions from PISA can be used.

The results of interviews with fourth grade teachers in several elementary schools in Enrekang district, South Sulawesi, as a preliminary study, gained information that actually learning has been shown to assess cognitive, psychomotor, and affective aspects, but the evaluation tool in this case was the test instrument or test sheet used have not been able to measure these three aspects, the test sheet used is still more emphasis on the knowledge aspect. Heri et al., (2017) stated that different students' cognitive abilities can affect how students solve problems so the patterns that used can variative, therefore it needs to make the right measurements (Kurniawan et al., 2018)

The researcher also found that many students still had difficulties when given the questions with problem solving from reading texts, they still needed to be guided. The tests used also still use the questions contained in the books used in learning that are not based on student needs, for example containing aspects of scientific literacy by paying attention to the environment or culture around students, that efforts to improve the quality of education in Indonesia can be carried out and can compete with other countries.

Sayakti (2003)emphasized the importance of learning to use the concept of environment and culture, especially local culture as a source of learning so that learning outcomes are more meaningful for students. Research Emdin (2011) showed that the link between science and culture can affect the improvement of students' academic results. The results of Atmojo (2015) on the effectiveness of science subject with a cultural approach that can make learning more meaningfully.

Based on the description above, the purpose of this research is to make a scientific literacy test instrument that connects the culture and environment around students or commonly known as ethnoscience that is reliable, feasible and practical as well as its benefits for institutions as a reference in contributing to improving the instrument and developing test instruments for students in science learning class IV in elementary school.

\section{LITERATURE REVIEW}

Based on a review of research on test instruments as evaluation materials to determine the extent to which students' ability in solving problems or assignments can be used as evaluation. According to Adnyana et al., (2013) a test is an instrument or a systematic procedure tool consisting of a set of questions or tasks to measure a certain behavior in students using a numerical scale or certain categories. The test is a planned systematic procedure by the evaluator to compare the behavior of two or more students, but in reality, the test generally consists of a set of questions or 
tasks that must be answered by students (Khoirudin et al., 2017)

Sinaga (2015) suggested that the test is a systematic, valid, reliable and objective assessment tool to determine the abilities, skills, and level of students' knowledge of teaching materials in the form of a task or problem that must be completed by a student or a group of students. Aisyah (2013) argued that the test is a form of giving assignments or questions that must be done by who is being tested. To make learning more meaningful and contextual, one of the things that can be done is to use culture or the surrounding environment in learning.

According to Sudarmin et al., (2013) the scientific approach recommended in education in Indonesia today is ethnoscience, that is original knowledge in the form of language, customs and culture, morals as well as technology created by certain people or people that has scientific knowledge. Aza Nuralita, (2020) this approach is a strategy for creating an ethnoscience learning environment and learning planning that integrates culture as an ingredient of the science learning process. The application of science teaching and learning with an ethnoscience approach, the teacher's skills needed to connect of genuine knowledge with scientific knowledge.

The importance of ethnoscience learning for special exploration of genuine knowledge in a society to be studied which can be a bridge to formal science as a study of learning in schools (Bahardur, 2018).This is in line with the opinion of Nurkhalisa et al., (2017) that the learning process is not only done in the classroom but the students can also learn from the environment and society. The results of Suardana (2014)which stated that the ethnoscience integrated science learning process provides opportunities for students to express their various curiosity, be involved in the process of making healthy conclusions. Integrated understanding as a result of learning with an ethnoscience approach requires the creation of meaning by students on the substance of the field of study and its context.

\section{MATERIALS \& METHODS}

This research was conducted at SDN 76 Kasambi, SDN 157 Cakke, and SDN 39 Cakke. The research method used research and development (R\&D) methods with the ADDIE research design (analysis, Design, Development, Implementation, and Evaluation) adopted from (Dick, W. and Carey, 1996). The object of this research was a test instrument containing ethnoscience to measure the scientific literacy ability of fourth grade elementary school students that is reliable, feasible and practical. The procedures for the stages in this research as follow:

\section{Stage of analysis (analysis)}

The analysis stage is the initial stage of research to determine the potential and problems that occur in learning, especially in science learning related to scientific literacy. The analysis phase of the development of tests contained ethnoscience, scientific literacy skills, revised 2013 curriculum, and previous research regarding the development of tests containing ethnoscience. While the preliminary study aimed to obtain information on the suitability of the literature reviewed with the conditions of the preliminary study through interviews with teachers.

\section{Design stage}

At the design stage, the researcher began the initial design of the questions which consists of determining the form of the test, determining the aspects of scientific literacy to be used, determining indicators and designing test. The explanation of these steps as follow: a) determining form of the test, which is in the form of multiple choice questions with 4 answer options taking into the scientific literacy ability of students to be involved in answering the reasons for the questions; b) determine aspects of scientific literacy skills that were developed in this case the content domain and cognitive 
domain; c) determine indicators based on aspects of scientific literacy to be developed; d) designing the grid, that is the design of plan is presented in tabular form, in the table there are points such as aspects of scientific literacy, indicators, questions, and answer keys; e) compiling a test instrument containing ethnoscience consisting of a cover page, a preface, a table of contents, a list of aspects of scientific literacy, a grid of questions, general instructions and test questions.

\section{Development Phase (development)}

The final result of this research was the development of scientific literacy test instruments in the form of scientific literacy test instruments containing ethnoscience complete with plan. The instrument design developed includes a scientific literacy test instrument containing ethnoscience in the form of multiple-choice questions. The questions in the developed instrument were adjusted to aspects of scientific literacy, namely the content domain and cognitive domain as well as the level of student ability. The development of instrument design was adjusted to the basic competencies (KD) to be achieved. The process of developing the test instrument design is equipped with developing expert validation instruments including evaluation experts, materials, scientific literacy to see the test instruments developed. Furthermore, it is calculated and described using Aiken'V validation.

\section{Implementation phase (implementation)}

Came up to implementation stage, the test instruments were carried out on a small and large scale. Small scale was implemented at SDN 76 Kasambi and large scale at SDN 157 Cakke and SDN 157 Cakke, Enrekang Regency. At this stage it was carried out to obtain data in an effort to measure students' scientific literacy skills through working on the developed test instruments. Data analysis used the reliability, discriminatory, and level of difficulty test stages and analyzed using the SPSS 16 application. Further analysis was carried out based on a teacher response questionnaire to determine the practicality or implementation of the developed ethnoscience-laden scientific literacy test instrument.

\section{Evaluation stage}

At this stage, it is done by evaluating the results of trials using test instruments, whether they are able to measure students' scientific literacy abilities. This stage can be continued at the mass production stage if the test instrument product to measure students' scientific literacy skills in science learning that has been tested is declared feasible, reliable and practical and does not get a response or comment from the experts, then mass production can be carried out.

The validity of the data in this study is expressed by two kinds of tests, there were the first test of credibility (credibility) can be called the validity test, which is a technique to measure the reliability of the data that is checked through the completeness of the data obtained from various sources. Second, the research dependence test (dependability) is also called reliability which is a representation of a series of data search activities that are traced. Before the researcher got the data, the instrument was validated by consulting experts in the field of developing test instruments. The instrument that was consulted was in the form of a test instrument validation sheet containing ethnoscience in measuring scientific literacy skills.

The development of the test instrument started from the validation of expert, in this study researcher used five expert validators, there were evaluation experts, materials, scientific literacy, practitioner 1 and practitioner 2. Furthermore, testing the quality of the instrument by testing content validity. Instruments that were declared valid according to all experts, can then be tested. This is in line with the research of Zakaria et al., (2020) which stated that 
validity is the level of reliability and expertise of the measuring instrument used. The instrument is said to be valid, meaning that the measuring instrument used to obtain the data is valid or can be used to measure what should be measured.

Validity carried out with experts according to their fields, the aimed is to find out that the test items can be said to be suitable for use and data processing is carried out using content validity analysis, reliability, level of measurement, differentiating power, while to find out how practical the test items are seen from the results. the percentage of teacher response questionnaires whose magnitude is more than $71 \%$ based on the practicality criteria of teacher questionnaire assessment (Ningrum \& Lutfi, 2019).

\section{RESULT \& DISCUSSION \\ 1. The Validity of Ethnoscience- Contented Scientific Literacy Instruments}

Before researcher done trials, the test instrument developed was tested for validity to produce the right test to measure the desired ability. The validity test was carried out by 5 experts, there were evaluation experts, materials, scientific literacy, practitioner 1 and practitioner 2 , in this case the intended practitioner is a grade IV elementary school teacher. The validity test was carried out to see the suitability of the material, construction, and language of the developed test instrument. According to Hendryadi (2017)validity describes the extent to which the measuring instrument (test) actually measures what it is intended to measure.

Expert validators were asked to provide an assessment of the instruments that have been made by researchers. Expert validators assess the quality of the ethnoscience-laden scientific literacy instruments made and their suitability with the context of science, competence, content domain, cognitive domain, and scientific attitude. The results of the expert assessment of the test instrument are then calculated using the Aiken'v formula that has been designed in Microsoft Excel calculations.

The coefficient of the expert agreement was then compared with the validity coefficient of the Aiken'V table. The content validity value was consulted with the Aiken'v table, if the validity coefficient is "1" it means that the item can be said to be valid with an error rate of $5 \%$. If the coefficient of expert agreement 0.80 then the item is said to be valid or adequate. Conversely, if the coefficient of expert agreement $<0.80$ then the item is not valid. The following is the result of calculation data from experts using the Aiken'V formula, which can be seen in table 1 .

Table 1. Expert Coefficient

\begin{tabular}{|l|l|l|}
\hline \multicolumn{3}{|c}{ Table 1. Expert Coefficient } \\
\hline No. Item & Aiken Coefficient & Criteria \\
\hline 1 & 0.9 & Valid \\
\hline 2 & 0.9 & Valid \\
\hline 3 & 0.6 & Not Valid yet \\
\hline 4 & 1.0 & Valid \\
\hline 5 & 0.9 & Valid \\
\hline 6 & 0.9 & Valid \\
\hline 7 & 1.0 & Valid \\
\hline 8 & 0.9 & Valid \\
\hline 9 & 0.7 & Not Valid yet \\
\hline 10 & 0.9 & Valid \\
\hline 11 & 0.7 & Not Valid yet \\
\hline 12 & 0.9 & Valid \\
\hline 13 & 0.9 & Valid \\
\hline 14 & 1.0 & Valid \\
\hline 15 & 0.9 & Valid \\
\hline 16 & 1.0 & Valid \\
\hline 17 & 0.9 & Valid \\
\hline 18 & 1.0 & Valid \\
\hline 19 & 1.0 & Valid \\
\hline 20 & 1.0 & Valid \\
\hline
\end{tabular}

Items that have been tested on expert validators were then revised by taking into the suggestions given by experts then it became items that can better measure scientific literacy skills. Based on the data presented in table 1, information can be obtained regarding the level of validity of the items based on the Aiken'V formula. The number of 20 items said to be valid with the Aiken'V index exceeding 0.80. Item numbers 4,7,14,16,18,19,20 with Aiken'V 1 index, for question numbers $1,2,5,6,8,10,12,13,15,17$ with Aiken'V index 0.90 , item numbers 3.9 , and 11 were declared invalid because they were in the Aiken'V index $>0.80$. 
Scientific literacy instruments containing ethnoscience that have been validated by experts are then tested. The scientific literacy instrument containing ethnoscience was tested on a small scale at SDN 76 Kasambi with 18 students and on a large scale at SDN 39 Cakke and SDN 157 Cakke grade IV with 58 students.

\section{Reliability}

The reliability of the multiple-choice scientific literacy test instrument with ethnoscience developed by the help of SPSS 16 with the Cronbach's alpha formula. The reliability test was based on small and large scale, the estimated reliability coefficient can be seen in the attachment of SPSS 16 reliability test output. The results of the analysis of reliability testing from the data from small-scale and large-scale trials obtained the coefficients in table 2 , as follows:

Table 2. Reliability Test Result

\begin{tabular}{|c|c|c|}
\hline Reliability & & Criteria \\
\hline Small Scale Test & 0.671 & High \\
\hline Big Scale Test & 0.711 & High \\
\hline
\end{tabular}

The results of the calculation reliability of the scientific literacy instrument contained ethnoscience showed that the instrument was declared reliable. In a small-scale trial, the level of reliability of the item was 0.671 and showed a high level of reliability. In large-scale trials, the reliability of the questions showed the results of 0.711 and can be categorized as high so that the test instrument developed can be said to be reliable and feasible to use.
In accordance with the opinion of Rusilowati et al., (2016) reliability is the level or degree of consistency of an instrument. Test reliability is concerned with the question of whether a test is researched and can be trusted in accordance with predetermined criteria. To determine the level of reliability of the instrument, the r11 price category is used which is obtained and then compared with the rtable price with $=5 \%$. Calculations that produce rcount $>$ rtable then the question is reliable. The following is table 3 of the reliability criteria of the question.

Table 3. Reliability Test Criteria

\begin{tabular}{|l|l|}
\hline Interval Coefficient & Reliability Level \\
\hline $0,8<\mathrm{r} \leq 1,0$ & Very High \\
\hline $0,6<\mathrm{r} \leq 0,8$ & High \\
\hline $0,4<\mathrm{r} \leq 0,6$ & Middle \\
\hline $0,2<\mathrm{r} \leq 0,4$ & Low \\
\hline $\mathrm{r}<0,2$ & Very Low \\
\hline
\end{tabular}

Based on trials on a small and large scale, the developed instrument can be said to be reliable, with a reliability coefficient of $0.6<\mathrm{r} 0.8$.

\section{Different Power}

The data from the small-scale and large-scale trials were then analyzed to determine the characteristics of each item. Analysis of multiple-choice test items for science literacy questions for elementary school students for grade IV, namely with SPSS 16, this analysis aimed to determine the differentiating power and level of difficulty of the questions. The explanation of the results of the small-scale power difference is as follows:

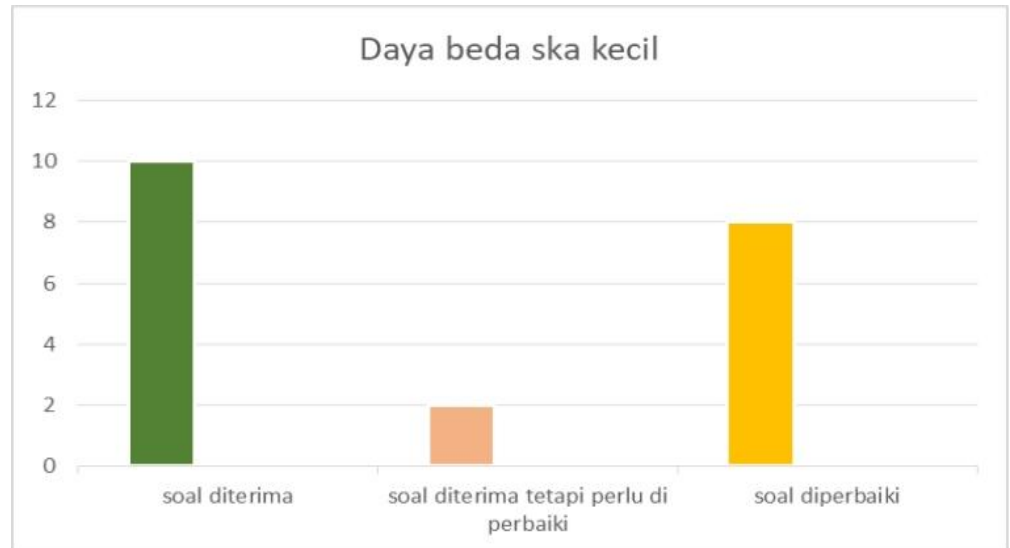

Figure 1. Differing Power of Small-Scale Questions, Daya Beda skala kecil: Different Power Small Scale, Soal diterima: Test was accepted, Soal diterima tetapi perlu diperbaiki: Test was accepted but need to revised, Soal diperbaiki: Test was revised 
Based on Figure 1, a small-scale test with 20 scientific literacy questions containing ethnoscience for grade IV Elementary School. In the analysis of the differentiating power of 20 questions, there were criteria according to the classification of distinguishing power according to Croker and Algina in A. Rusilowati et al., (2017) which is $0.40 \mathrm{D} 1.00$ Question was accepted; $0.30 \mathrm{D}<0.40$ Question was accepted, but needs to be improved; $0.20 \mathrm{D}$ $<0.30$ Test revised; and $0.00 \mathrm{D}<0.20$ Questions were not used / discarded. The researcher corrected the questions with the help of the fourth-grade teacher at SDN 76 Kasambi, after that the researchers conducted a large-scale trial at SDN 39 Cakke and SDN 157 Cakke. The test results are as follows:

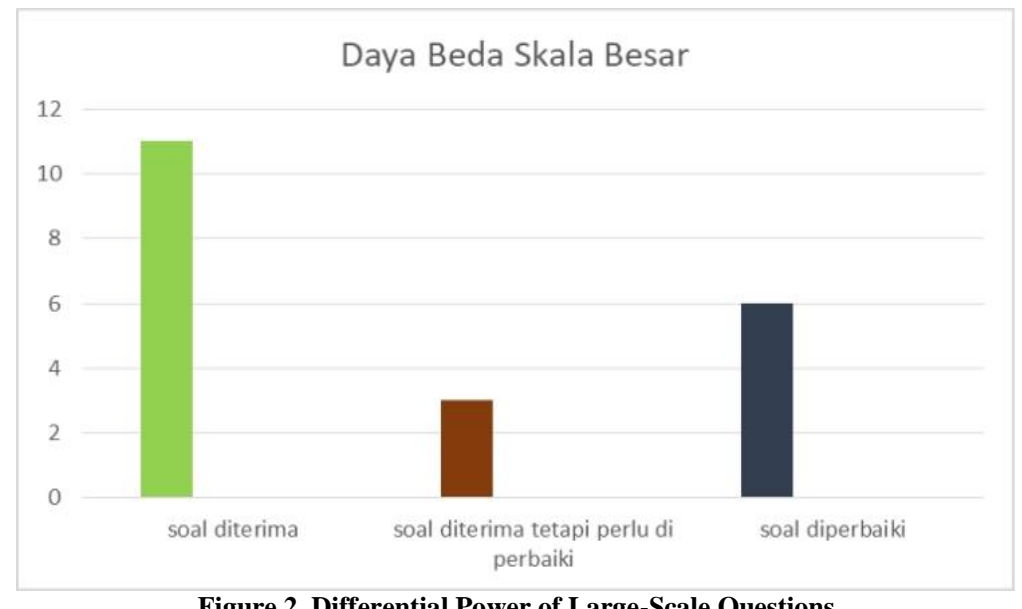

Figure 2. Differential Power of Large-Scale Questions

The results of the quantitative analysis for the discriminatory power of questions on a small scale obtained 20 multiple choice questions for grade IV elementary school. In the analysis of the differentiating power of the 20 questions, there were criteria for the items to be accepted, namely 10 items, items were accepted but needed to be corrected, namely 2 items, and 8 items were corrected.
The test of different power on a large scale obtained 20 multiple choice questions for grade IV elementary school. The analysis of the power of difference from the 20 questions contained 11 items for the criteria for the items to be accepted, 3 items were accepted but needed to be corrected, and 6 items were corrected.

\section{Difficulty Level}

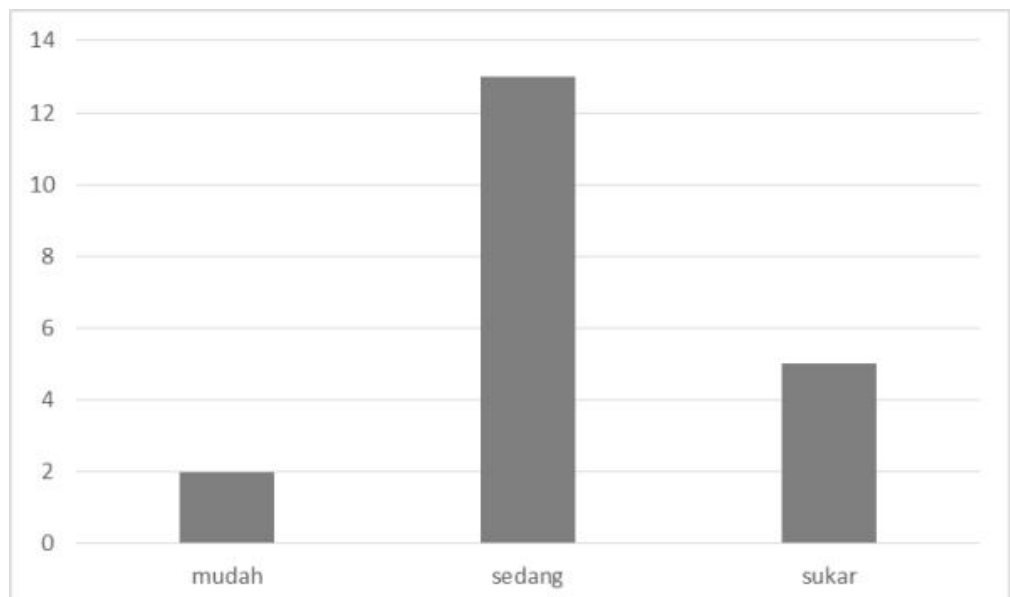

Figure 3. Results of the Analysis of the Difficulty Level of the Small-Scale Test, Mudah: easy, Sedang: medium, Sukar: difficult 
The characteristics of the items that were searched in addition to the test of different power were the level of difficulty of the questions. The difficulty level test aimed to find out which questions were classified as difficult, easy, and moderate.
The results of the item analysis on the small-scale test can be seen in Figure 3.

The analysis of the difficulty level of the large-scale test is presented in Figure 4 as follows:

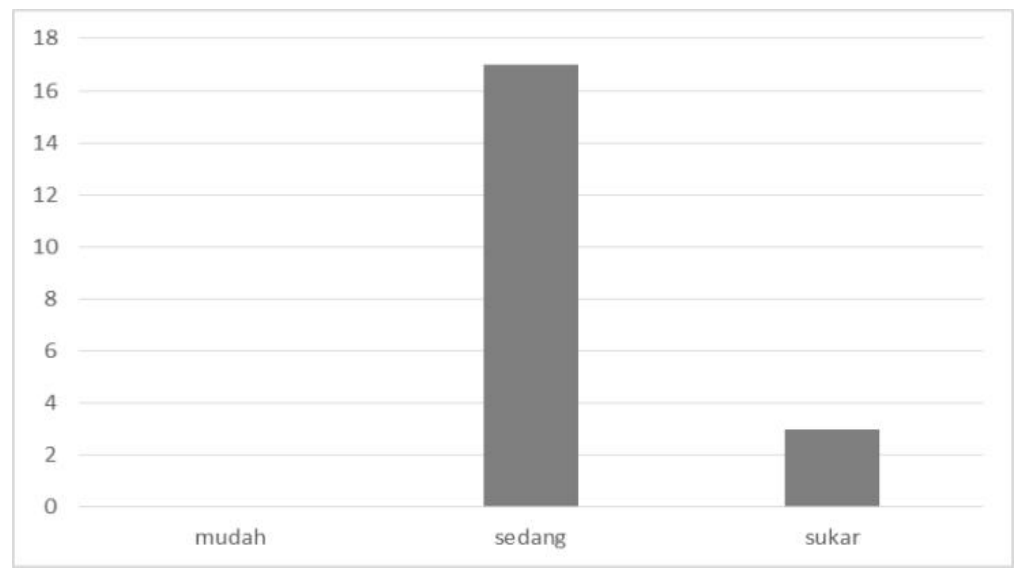

Figure 4. Results of the Analysis of the Difficulty Level of the Large-Scale Test

Based on the image of the difficulty level, the results of quantitative analysis on a small scale for the level of difficulty of the questions stated that, as many as 2 questions with easy criteria, 13 questions with medium criteria and 5 questions with difficult criteria. While the results of quantitative analysis on a large scale for the level of difficulty of the questions stated that as many 3 items with difficult criteria, 17 questions with moderate criteria and for easy criteria were not found in large-scale trials. This is in line with the opinion of Ani Rusilowati et al., (2016) which states that the index of difficulty level criteria in the difficult category is 0.00 TK 0.30 ; medium category 0.31 Kindergarten 0.70 and for easy category 0.71 Kindergarten 1.00.

\section{Practicality of Science Literacy Instruments with Ethnoscience Content}

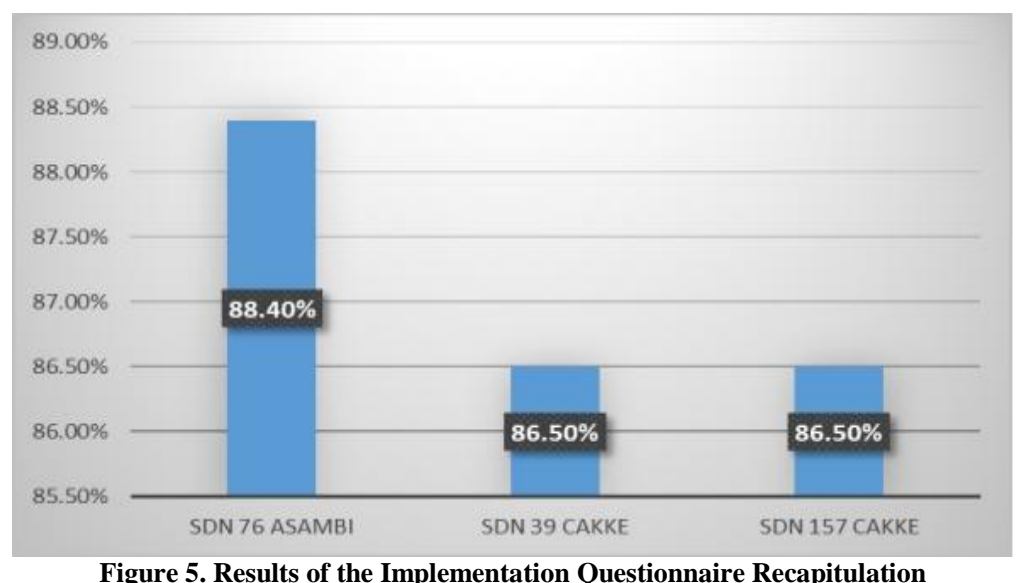

The practicality test of the instrument was obtained from the results of the teacher's responses through practical analysis of 4 raters, namely fourth grade teacher practitioners at SDN 76 Kasambi, SDN 157 Cakke, and SDN 39 Cakke. Each teacher is given a questionnaire and a draft test instrument that has been developed. The teacher filled out a questionnaire based on analysis and experience, understanding each question item in the implementation or practicality questionnaire. The researcher 
did not provide any data on the demands of the assessments given by the teachers. The results of filling out the questionnaire for the assessment of scientific literacy instruments containing ethnoscience developed in table 5

Based on Figure 5, the results of the questionnaire recapitulation carried out by the Rater, from 4 raters using a Likert scale of 1 to 4 , the criteria were very practical, the evidence in classifying or formulating a scientific literacy test instrument containing ethnoscience which was developed practically or not, the researchers provided guidelines regarding practicality criteria. Clearer scoring guidelines can be seen in table 4

Table 4. Criteria for the percentage of practicality

\begin{tabular}{|l|l|}
\hline Interval score \% & Criteria \\
\hline $86 \%-100 \%$ & Very Practical \\
\hline $71 \%-85 \%$ & Practical \\
\hline $56 \%-70 \%$ & Practical Enough \\
\hline $41 \%-5 \% \leq 25 \%-40 \%$ & Less Practical \\
\hline
\end{tabular}

Practicality can be made a decision based on the percentage of practicality in table 4. The percentages obtained from teacher assessments are $88.4 \%, 86.5 \%$, and $86.5 \%$, then the scientific literacy test instrument containing ethnoscience in science learning for grade IV elementary schools is found in very practical criteria. The researcher made a decision based on the teacher's assessment that the instrument developed could be used practically.

Santi \& Santosa (2016) stated that $86 \%$ more values were included in the very practical category. This means that the 20 multiple choice test questions of scientific literacy with ethnoscience content have met the requirements of the qualitative analysis of the questions. Based on the description above, it shows that the scientific literacy instrument containing ethnoscience is stated to be practical according to the teachers.

Astuti et al., (2012)stated that the development of evaluation tools provides an understanding of the concepts and methods of science, the impact of technology and on the environment. The practicality of scientific literacy-based assessment instruments is a measure of the extent to which assessment instruments are easy to use and do not provide additional burdens for students (Putri, 2020)

In line with the research on the practicality of the questions from Raudah et al., (2020) the practicality of the assessment instrument, according to the teacher's response, is in the good category with a percentage of $75 \%$, while according to the students, it is in the very good category with a percentage of $94 \%$. This assessment instrument is easy to use and does not provide an additional burden for teachers and students, in this case the assessment instrument is very practical.

\section{CONCLUSION}

The scientific literacy instrument containing ethnoscience, which was developed with a multiple-choice test with reasoned results, resulted in 20 questions based on material indicators and scientific literacy indicators on the theme of 9 Kayanya Negeriku, grade IV.

The scientific literacy instrument containing ethnoscience developed through testing includes content validity, reliability, discriminating power, level of difficulty and practicality with SPSS 16 program. Content validity was analyzed using Aikens'V with an index of expert agreement in the range of 0.60 to 1.00 .

The test of the reliability calculation on the scientific literacy instrument with ethnoscience shows that the instrument is declared reliable. In small-scale trials, the level of reliability of the item is 0.671 and showed a high level of reliability. In largescale trials, the reliability of the questions shows the results of 0.711 and can be categorized as high so that the test instrument developed can be said to be reliable and feasible to use.

The results of the analysis of the differentiating power of questions on a small scale obtained 20 multiple choice questions for grade IV elementary school. In the analysis of the differentiating power of the 20 questions, there were criteria for the items to be accepted, namely 10 items, 
items were accepted but needed to be corrected, namely 2 items, and 8 items were corrected. The results of the analysis of the test of differentiating power on a large scale obtained 20 multiple choice questions for grade IV elementary school. The analysis of the power of difference from the 20 questions contained 11 items for the criteria for the items to be accepted, 3 items were accepted but needed to be corrected, and 6 items were corrected.

The practicality of the instrument can be decided based on the percentage of practicality. The percentages obtained from teacher assessments are $88.4 \%, 86.5 \%$, and $86.5 \%$, then the scientific literacy test instrument containing ethnoscience in science learning for grade IV elementary schools, is in very practical criteria based on the percentage of implementation criteria or the practicality of the instrument in the $86 \%-100$ category $\%$.

It can be concluded the scientific literacy instrument containing ethnoscience in science learning theme 9 "Kayanyaku Negeriku" for grade IV Elementary School students that was developed has met the criteria of being valid, reliable, feasible, and practical.

\section{Acknowledgement: None}

\section{Conflict of Interest: None}

\section{Source of Funding: None}

\section{REFERENCES}

1. Adawiyah, R., \& Wisudawati, A. W. (2017). Pengembangan Instrumen Tes Berbasis Literasi Sains: Menilai Pemahaman Fenomena Ilmiah Mengenai Energi. Indonesian Journal of Curriculum, 5(2), 112-121.

2. Adnyana, K. J., Lasmawan, I. W., \& Koyan, I. W. (2013). Pengaruh Model Pembelajaran Rekonstruksi Sosial Terhadap Keterempilan Berpikir Kreatif Dan Pemahaman Konsep IPS. E-Journal Program Pascasarjana Universitas Pendidikan Ganesha, 3.
3. Aisyah. (2013). Pengembangan Soal Tipe PISA di Sekolah Menengah Pertama. Edumatica, 03(April), 27-34.

4. Aji, S., Wiyanto, \& Nugroho, S. E. (2015). Pengembangan Asesmen Untuk Mengukur Kemampuan Memecahkan Masalah, Bekerjasama Dan Berkomunikasi Calon Guru Fisika. Journal of Innovative Science Education, 4(2), 24-33.

5. Anggriani, A., Sarwi, S., \& Masturi, M. (2020). The Effectiveness of Guided Discovery in Distance Learning to Improve Scientific Literacy Competencies of Primary School Students. Journal of Primary Education, $\quad 9(5)$, 454-462. https://doi.org/10.15294/jpe.v9i4.42600

6. Ariningtyas, A., Wardani, S., \& Mahatmanti, W. (2017). Efektivitas Lembar Kerja Siswa Bermuatan Etnosains Materi Hidrolisis Garam untuk Meningkatkan Literasi Sains Siswa SMA. Journal of Innovative Science Education, 6(2), 186196.

https://doi.org/10.15294/jise.v6i2.19718

7. Astuti, W. P., Prasetyo, A. P. B., \& Rahayu, E. S. (2012). Pengembangan Instrumen Asesmen Autentik Berbasis Literasi Sains Pada Materi Sistem Ekskresi. Lembaran Ilmu Kependidikan, 41(1).

8. Atmojo, S. E. (2015). Learning which oriented on local wisdom to grow a positive appreciation of batik jumputan (ikat celup method). Jurnal Pendidikan IPA Indonesia, 4(1), $48-55$. https://doi.org/10.15294/jpii.v4i1.3501

9. Aza Nuralita. (2020). Analisis penerapan model Pembelajaran berbasis etnosains dalam pembelajaran tematik SD. MIMBAR PGSD Undiksha, 4(1), 1-8.

10. Azimi, Rusilowati, A., \& Sulhadi, S. (2017). Pengembangan Media Pembelajaran IPA Berbasis Literasi Sains untuk Siswa Sekolah Dasar. PSEJ (Pancasakti Science Education Journal), 2(2), 145. https://doi.org/10.24905/psej.v2i2.754

11. Bahardur, I. (2018). Kearifan Lokal Budaya Minangkabau Dalam Seni Pertunjukkan Tradisional Randai. JENTERA: Jurnal Kajian Sastra, 7(2), 145. https://doi.org/10.26499/jentera.v7i2.932

12. BouJaoude, S. (2002). Balance of scientific literacy themes in science curricula: The case of Lebanon. International Journal of Science Education, 24(2), 139-156. 
Nur khairiyatul Mar'ah et.al. Development of science literature instruments contained ethnoscience in science subject for class IV elementary school students.

$$
\text { https://doi.org/10.1080/0950069011006649 }
$$

13. Emdin, C. (2011). Droppin' Science and Dropping Science: African American Males and Urban Science Education. Journal of African American Males in Education, 2(1), 66-80.

14. Fu'adah, H., Rusilowati, A., \& Hartono. (2017). Pengembangan Alat Evaluasi Literasi Sains untuk Mengukur Kemampuan Literasi Sains Siswa Bertema Perpindahan Kalor dalam Kehidupan. Lembaran Ilmu Kependidikan, 46(2), 51-59.

15. Haka, N. B., Hamid, A., Nurhidayah, N., Kesumawardhani, A. D., Rudhini, M., \& Riski, R. A. (2019). Pengembangan Instrumen Evaluasi Two-Tier Multiple Choice Terhadap Literasi Sains Berbantuan Personal Computer. Biosfer: Jurnal Tadris Biologi, 10(2), 201-214. https://doi.org/10.24042/biosfer.v10i2.5755

16. Hendryadi, H. (2017). Validitas Isi: Tahap Awal Pengembangan Kuesioner. Jurnal Riset Manajemen Dan Bisnis (JRMB) Fakultas Ekonomi UNIAT, 2(2), 169-178. https://doi.org/10.36226/jrmb.v2i2.47

17. Heri, L., Rusilowati, A., \& Raharjo, T. J. (2017). Pengembangan Instrumen Penilaian Psikomotor Senam Lantai dalam Pembelajaran Penjasorkes pada Siswa Sekolah Dasar. Journal of Research and Educational Research Evaluation, 6(1), 1929. https://doi.org/10.15294/jrer.v6i1.16204

18. Khoirudin, A., Dwi Styawati, R., \& Nursyahida, F. (2017). Profil Kemampuan Literasi Matematika Siswa Berkemampuan Matematis Rendah Dalam Menyelesaikan Soal Berbentuk Pisa. Aksioma, 8(2), 33. https://doi.org/10.26877/aks.v8i2.1839

19. Kurniawan, B. R., Reyza, M., \& Taqwa, A. (2018). Pengembangan Instrumen Tes Kemampuan Pemecahan Masalah Fisika pada Materi Listrik Dinamis. Jurnal Pendidikan: Teori, Penelitian, Dan Pengembangan, 3(11), 1451-1457.

20. Lulu, A. M., Rusilowati, A., \& Linuwih, S. (2016). Pengembangan Instrumen Asesmen Literasi Sains Tema Energi. Journal of Primary Education, 5(2), 147-154. https://doi.org/10.15294/jpe.v5i2.12905

21. Ningrum, I. R., \& Lutfi, A. (2019). Permainan House of Chemistry Sebagai Media Pembelajaran Pada Materi Hidrokarbon Kelas XI SMA. Unesa Journal of Chemical Education, 8(2), 43-49.
22. Nurkhalisa, S., Fari, F., \& Ummayah, D. (2017). Etse-Module "The Benefits of Acidic Bases in Life" Ethnoscience Based Demak Society in the Utilisation of Lime. International Journal of Science and Research (IJSR), 6(7), 1396-1400. https://doi.org/10.21275/art20175389

23. OECD. (2018). PISA 2018 Draft analytical Frameworks. In PISA 2018 Draft analytical Frameworks (Issue May 2016). https://www.oecd.org/pisa/data/PISA-2018draft-frameworks.pdf

24. Putri, R. K. (2020). Pengembangan Instrumen Tes Literasi Sains Siswa Pada Topik Keanekaragaman Makhluk Hidup. Diklabio: Jurnal Pendidikan Dan Pembelajaran Biologi, 4(1), 71-78. https://doi.org/10.33369/diklabio.4.1.71-78

25. Raudah, Y., Sukron, M., \& Susilawati, W. O. (2020). Pengaruh Model Inquiry Terhadap Hasil Belajar Muatan IPS Siswa Kelas IV: Studi Literatur. International Journal of Technology Vocational Education and Training, 1(2), 137-142.

26. Rostikawati, D. A., \& Permanasari, A. (2016). Rekonstruksi bahan ajar dengan konteks socio-scientific issues pada materi zat aditif makanan untuk meningkatkan literasi sains siswa. Jurnal Inovasi Pendidikan IPA, 2(2), 156. https://doi.org/10.21831/jipi.v2i2.8814

27. Rusilowati, A., Fakhriyah, F., Masfuah, S., Roysa, M., \& Rahayu, E. S. (2017). Student's science literacy in the aspect of content science? Jurnal Pendidikan IPA Indonesia, 6(1), 81-87. https://doi.org/10.15294/jpii.v6i1.7245

28. Rusilowati, Ani, Kurniawati, L., Nugroho, S. E., \& Widiyatmoko, A. (2016). Developing an instrument of scientific literacy asessment on the cycle theme. International Journal of Environmental and Science Education, 11(12), 5718-5727.

29. Santi, I. K. L., \& Santosa, R. H. (2016). Pengembangan Perangkat Pembelajaran Menggunakan Pendekatan Saintifik pada Materi Pokok Geometri Ruang SMP. PYTHAGORAS: Jurnal Pendidikan Matematika, 11(1), 35. https://doi.org/10.21831/pg.v11i1.9673

30. Sayakti, L. (2003). Implementasi Konsep Lingkungan Hidup sebagai Sumber Belajar dalam Pembelajaran IPS di Sekolah Dasar. Sps UPI. 
Nur khairiyatul Mar'ah et.al. Development of science literature instruments contained ethnoscience in science subject for class IV elementary school students.

31. Sinaga, T. N. (2015). Pengembangan Soal Model Pisa Mata Pelajaran Ilmu Mengetahui Penalaran Siswa Kelas Ix. Jurnal Inovasi Dan Pembelajaran Fisika, 2(2), 194-197.

32. Suardana, I. N. (2014). Analisis Relevansi Budaya Lokal Dengan Materi Kimia SMA Untuk Mengembangkan Perangkat Pembelajaran Inkuiri Terbimbing Berbasis Budaya. Jurnal Pendidikan Indonesia, 3(1), 337-347. https://doi.org/10.23887/ika.v17i2.19853

33. Sudarmin, Rosyidah, A. N., \& Siadi, K. (2013). Pengembangan Modul Ipa Berbasis Etnosains Zat Aditif Dalam Bahan Makanan Untuk Kelas Viii Smp Negeri 1 Pegandon Kendal. USEJ - Unnes Science Education Journal, 2(1), 133-139. https://doi.org/10.15294/usej.v2i1.1765

34. Sudiatmika, A., Rustaman, N., \& Zainul, A. (2010). Komparasi Hasil Analisis Butir Soal
Literasi Sains Budaya Bali Menggunakan Program Berbeda. Jurnal Pendidikan Dan Pembelajaran (JPP), 17(2), 111-117.

35. Trnova, E. (2014). IBSE and Creativity Development. Science Education International, 25(1), 8-18.

36. Zakaria, L. M. A., Purwoko, A. A., \& Hadisaputra, S. (2020). Pengembangan Bahan Ajar Kimia Berbasis Masalah Dengan Pendekatan Brain Based Learning: Validitas dan Reliabilitas. Jurnal Pijar Mipa, 15(5), 554. https://doi.org/10.29303/jpm.v15i5.2258

How to cite this article: Mar'ah NK, Rusilowati A, Purwanti E. Development of science literature instruments contained ethnoscience in science subject for class IV elementary school students. International Journal of Research and Review. 2021; 8(9): 423-435. DOI: https://doi. org/10.52403/ijrr.20210954 